Journal of Awareness

Cilt / Volume 5, Say1 / Issue 2, 2020, pp. 201-212

E - ISSN: 2149-6544

URL: https://www.ratingacademy.com.tr/ojs/index.php/joa

DOİ: https://doi.org/10.26809/joa.5.016

Araştırma Makalesi / Research Article

\title{
KENTSEL GÜVENLİK İHTIYACININ TOPLUMSAL VE MEKÂNSAL YANSIMASI: KAPILI TOPLULUKLAR ${ }^{1}$
}

\author{
SOCIAL AND SPATIAL REFLECTION OF THE NEED FOR URBAN \\ SECURITY: GATED COMMUNITIES
}

\section{Demet ONUR*}

\author{
* Dr. Ögrr. Üyesi, Kirklareli Üniversitesi, \\ TÜRKIYE, e-mail: demetonur@klu.edu.tr \\ ORCID: https://orcid.org/0000-0002-4404-4991
}

Geliş Tarihi: 9 Ocak 2020; Kabul Tarihi: 25 Nisan 2020

Received: 9 January 2020; Accepted: 25 April 2020

\begin{abstract}
ÖZET
Kentler, toplumlar için güvenlik ve barınma ihtiyacının karşılandiğı mekânlardır. Ancak, kentler günümüzde hızlıca büyümüs, kalabalıklaşmış ve yoğunlaşmışlardır. Bu kentleşme hızı, tüm ana kentlerde güvensizlik, risk, tehlike, yaşam kalitesi kaygısı ve statü kaygısı gibi toplumsal olguların sorun haline gelmesine yol açmıştır. Yoğun kentsel mekânların, kalabalıkların ve kentsel yoksulluğun neden olduğu suçlardan duyulan korku mekânsal farklılaşma ve statü ayrımı gibi durumlarla mekânsal korunma ihtiyacını doğurmuştur. Modern dünyanın yeni orta sınıfi yoksulluktan ve suçtan korkmaktadır. Bu korku, kentlerde kapılı toplulukları oluşturmuştur. Kapılı toplulukları ortaya çıkaran en büyük etken güvenlik ihtiyacıdır. Yaşam kalitesini arttırmak, homojen gruplarla birlikte yaşama isteği, gelir seviyesini tüketim unsurlarıyla mekânda göstermek gibi nedenler de kapılı topluluk oluşturma ihtiyaçlarının arasında sayılmaktadır. Kentsel güvenlik ihtiyacının doğurduğu dışa kapalı toplulukların oluşmasının başka temel nedeni de kentsel suçlardan uzak yaşama isteğidir.

Bu çalışmanin amacı, kentlerde toplumsal ve mekânsal farklılaşma süreciyle ortaya çıkmış kapılı toplulukları, sosyo-ekonomik ve mekânsal boyutlarıyla ele almaktır. Çalışmanın konusu ise, kentsel güvenlik ihtiyacıyla mekânsal eşitsizlik oluşturan kapılı toplulukların, kentlere suçu ortadan kaldırmak yerine sadece örttügünü ve bu durumun kentlerde sosyal eşitsizlik ve adaletsizlik yarattığını ortaya koymaktır. Bu çalışma, kentsel güvenliğin tüm kentte eşit yaşanabilmesi için mekânsal ayrışmanın kentsel politikalarla kontrol altına alınması gerektiğini vurgulamaktadır.
\end{abstract}

Anahtar Kelimeler: Kent, Risk Toplumu, Kentsel Güvenlik, Kentsel Suç, Kapılı Topluluklar. 


\begin{abstract}
Cities are spaces in which security and shelter needs are provided for societies. However cities have grown dramatically, become more crowded and more dense recently. This pace of urbanization has led to social phenomena such as insecurity, danger, anxiety of life quality and status anxiety becoming a problem in all the main cities. Fear of crimes caused by dense urban spaces, owercrowding and urban poverty has led to the need for spatial protection through situations such as spatial differentation and status discrimination. The new middle class of the modern world fears poverty and crime. This fear has formed gated communities in cities. The biggest factor that brings out gated communities is the need for security. The reasons such as increasing the quality of life, the desire to live together with homogeneous groups and showing the income level in the space with. The consumption elements are also considered among the needs to create a gated community. Another main reason for the formation of isolated communities, which are created by the need for urban security, is the desire to live away from urban crime.

The aim of this study is to handle the gated communities that emerged from the process of social and spatial dimensions. The subject of the study is to demonstrate that gated communities which create spatial inequality with the need for urban security, simply cover up rather than eliminate crime in cities, and that this create social inequality and injustice in cities. This study emphasizes that spatial segregation must be controlled by urban policies in order for urban security to be experienced equally in the entire city.
\end{abstract}

Keywords: Cities, Risk Society, Urban Security, Urban Crime, Gated Communities.

\title{
1. GíRiş
}

Küreselleşme sürecinin hızlı bir şekilde dünyayı özellikle mekân üzerinden etkisi altına aldığından bu yana statü, kimlik ve farklılıklar kentsel mekânlarda belirgin hale gelmiştir. Bu bağlamda, kentler toplumların hayat tarzının yansımasıdır. Bireylerin oluşturduğu bu hayat tarzı mekânı toplumsal bir kavrama dönüştürerek, güvenlik hissi ile donatılmış kültürel bir dönüşüm oluşturmuştur. Ayrıca kentlerde kamusal hayatı oluşturan kurallar mekân içerisinde şekillenmektedir. Bu bağlamda, toplumsal farklılaşma, suça maruz kalma korkusu, güvenli bir ortamda yaşama isteği ve böylece kalabalıktan kaçma isteği kapılı topluluklarda yaşam hayallerini güçlendirmiştir. Oluşan homojen topluluklar kendilerini korumak için konutlarda kurallar koymaktadır. Bu kurallar daha çok güvenlik olgusu üzerinde kurulmaktadır. Kentleşme arttıkça ve kentler büyüdükçe modern dünyanın izleri mekân üzerinden kentlerde tekrar üretilmektedir. Üretilen mekân neoliberal politikalarda eşliğinde kentlerde pazarlanmaktadır.

Kentler ilk ortaya çıktıkları zamanlardan bu yana güvenlik ve barınma ihtiyacının giderildiği mekânlar olarak düşünülmüştür. Ancak kentlerin hızla büyümesi, kalabalıklaşması ve yoğunlaşması kentlerin güvenlik sorunlarını ortaya çıkarmaktadır. Dünya ölçeğinde küreselleşme boyutuyla ele alındığında kentin dışarısı diye bir yerin kalmaması olasılığı daha da artmaktadır. Bu kentleşme hızı, kentlileşme kültürünü içselleştiremeyen toplumlarda güvensizlik, risk, tehlike, yaşam kalitesi kaygısı, statü gibi toplumsal olguları kentlerin ortasına bomba gibi koymaktadır. Kalabalık ve yoğun kentsel mekânlar suçun daha kolay işlendiği kontrolü zor alanlar oluşturmaktadır. Suçu oluşturan tek etken kalabalık değildir. Aynı zamanda yoksulluk ve yoksulluktan duyulan korku mekânsal farklılaşma ve statü ayrımı gibi durumlarla mekânsal korunma ihtiyacını doğurmuştur. Modern dünyanın yeni orta sınıfı yoksulluktan ve suçtan korkmaktadır. Bu bağlamda, kentsel mekânlarda korku ile kapılı topluluklarda izole olmak isteyen orta sınıf kent haklarından olan güvenli yaşama hakkını kullanmaktadır. Peki ya 
kentin geri kalanı? Güvenli yaşama hakkı tüm kente aittir. Kent haklarının eşit dağılmaması aynı kentsel alanda sosyal ayrım oluşturmaktadır.

Kent güvenliğinin sağlanması yerel yönetimlerin ve devletin kolluk kuvvetlerinin aldığı önlemlerle gerçekleşirken, risk toplumunun ve neo-liberal ekonomilerin oluşturduğu izole mekânsal yapılarla da yerine getirilmeye çalışılmaktadır. Ancak, bu durum mekânı tüketim nesnesi haline getirmektedir. Tüketim nesnesi olan mekân küreselleşmenin etkisiyle sınırsız sunulmakta ve bir emlak ürünü olmaktadır. Orta ve üst gelir grubunun kent kalabalığında elde edemediği güvenlik ve huzur ortamı bu mekânlarda yapay olarak oluşturulmaktadır. Kent ise organik ve dinamik bir yapıdır. Yapay ortam sonucunda kentsel güvenlik daha da sarsılmakta ve kentsel suçları daha da arttırmaktadır. Kentsel güvenlik ihtiyacı konusunda yeni bir sosyal süreç doğmaktadır. Yeni komşular, mahalle tadı, homojen toplumsal yapı ve korkunun olmadığı bir rüya etkisinin piyasaya sürüldüğü sosyal süreç kentlerin gündemindedir. Kentliler, kentlerin yoğun merkezlerinden uzak kapılar ardında risksiz bir hayatı tercih ettikleri için mutlu olmaktadır. Çünkü içeride sakin bir hayat varken güvenlikli sitenin dışı tehlikeli olabilmektedir. Kent güvenliği açısından küçük hayat alanlarının huzurlu yaşam ekseninde ele alındığı kentsel mekânlarda kentsel adaletsizlik ve eşitsizlik dişlanma ve ötekileştirmeye neden olmaktadır. Aynı zamanda gelir dağılımı eşitsizliği mekânda sosyal eşitsizliğe de neden olmaktadır. Bu bağlamda, kamusal alan daralmakta ve herkes aynı şekilde kentlerin kalbi olan kamusal alanlara kolay ulaşamamaktadır. Konut, kentin içerisinde korunaklı kaleler haline gelmektedir. Böylece, kentleşme olgusu mekânın sosyal ve ekonomik olarak ayrıştığı düşüncesi etrafında toplanmıştır. Kapılı topluluklara taşınma isteğinin ilk nedeni güvenliktir. Ancak günümüz neoliberal konut politikaları bu ihtiyacı bir tüketim unsuru haline getirerek mekânı üretmekte ve pazarlamaktadır. Duvarlar arkasında ev sahibi olmak dışarıda kalanlara her zaman korku ile bakmak ve ötekileştirmek boyutuyla yeni değerler üretmektedir. Bu bağlamda, mekân eşitsizliğin somutlaştığı alan haline gelmiştir.

Dünya'da 19. yüzyılda özellikle İngiltere'de banliyöleşme ile Türkiye'de ise 1980'li yıllarda başlayan ve kent merkezlerinden kent çeperlerine doğru yayılan bir kentleşme anlayışı ortaya çıkaran anlayış kapılı toplulukları ortaya çıkarmıştır. Bu mekânsal yeni biçim kentsel mekânlarda sosyo-mekânsal bir ayrışmaya neden olmaktadır.

\section{YÖNTEM}

Küreselleşme olgusunun tüketim ve liberal politikalar üzerindeki etkisi günümüzde mekânsal alışkanlıklara da yansımıştır. Bu durumun kentleşme üzerindeki etkisi araştırılarak, literatür taraması yapılmış ve betimsel bir çalışma ortaya konmuştur.

Çalışmanın Amacı: Bu çalışma, Dünya'da ve Türkiye'de giderek artan kapılı topluklarda yaşama alışkanlıklarının oluşturduğu toplumsal ve mekânsal ayrışmayı ortaya koymayı amaçlamaktadır.

Çalışmanın Önemi: Bu çalışmanın önemi güvenlik ve statü farkı nedeniyle kurulan kapılı toplulukların toplum üzerindeki etkisini incelemektir. Ayrıca, Türkiye'de kentsel mekânlar güvenlik ihtiyac1, liberal ekonomiler ve tüketim olgusunun etkisiyle toplumsal ayrışmaya neden olmaktadır.

\section{KENTSEL GÜVENLIK}

Kentlerde mekânı kullanırken en önem verilen nokta kalabalıkların etkisiyle güvenlik olmaktadır. Güvenliği mekâna yerleştirirken duvarların ardına gizlenme ve homojen bir yaşam oluşturma isteği vardır. Kent tanımlamalarına küreselleşme sürecinin hızlı değişimine odaklanarak yeni sorunlar, özellikle güvenlik olgusu yerleştirilmektedir. Yaşam kalitesi isteği öncelikle güvenlikle bağdaştırılmaktadır. 
Dünya'da ve Türkiye'de büyüyen kentlerde güvenliği sağlamak oldukça zorlaşmıştır. Güvensizlik hissini kentlerde oluşturan olguların en önemlisi kent yoksullarının neden olduğu düşünülen suçlardır. Bu bağlamda, sosyo-ekonomik dağılım kentlerde mekânsal ayrımlar oluşturmaktadır. Yoksulluk ve suç güvensizlik hissinin baş aktörü olarak algılanmaktadır. Ancak, kentsel güvenlik sadece suç korkusu üzerinden tanımlanmamaktadır. Kentliler her anlamda (iş, sosyal faaliyetler, tatil) kendilerini güvende hissetmek istemektedirler. Bu istek, 1992 yılında Avrupa Konseyi’nin Avrupa Kentsel Şartı'nda “suç, şiddet ve yasa dışı olaylardan arındırılmış bir kentte yaşama hakkı" (Arapkirlioğlu ve Yenerler: 1996) olarak somutlaştırılmıştır.

Kamusal yaşam alanı olarak kentte güvenliği sağlamak toplumsal bir ihtiyaçtır. $\mathrm{Bu}$ bağlamda, kentsel güvenlik "kentte yaşayan bireyin, kentsel yaşamına dair ihtiyaçlarını karşılarken ve ilişkilerini gerçekleştirirken bunu güvenlik içinde yapabilmesinin mümkün kılınmasıdır" (Kaypak, 2013:5). Güvenlik ve kentleşme karş1lıklı etkileşim içindedir. İnsanlar güvenlik için kentlerde yaşamaktadır. Aynı zamanda kalabalıklaşan kentsel mekânlar güvenliği zorlaştırmaktadır. Bireylerin yaşam kalitesi doğrultusunda kendilerini en rahat hissettikleri mekânsal yapılanma konutlarıdır. Bu konutları kentsel mekâna yerleştirirken kapılar, duvarlar ve güvenlik sistemleri kullanılmaktadır. Ancak bu topluluklarda bir ötekileştirme ve dışlayıcılık bulunmaktadir.

Kent merkezlerinde çalışan yeni orta sınıf yaşam alanı olarak kentin tehlikelerinden uzak yaşamak istemektedir. Mekâna yansıyan suç ve şiddet korkusu özel alan, kamusal alan ayrımı oluşturmaktadır. Özellikle Dünya'da II. Dünya Savaşı'ndan sonra banliyöleşme ve kentin çeperlerine yerleşme ile ortaya çıkan güvenlikli siteler kentsel alanlarda bu yapılaşmaya taban oluşturmuştur. Böylece günümüze kadar gelen ve kamusal alandan özel alana kayan yaşam adacıkları oluşmuştur. Kentsel güvenlik hakkını kullanma durumunun oluşturduğu bu yapılar sosyo-mekânsal ayrışmaya neden olmaktadır. Ayrıca, kentlerin merkezini terk eden kentliler kent merkezlerini birer çöküntü alanı olarak alt sınıfa bırakmıştır. Bu durum da çalışmanın temel konusu olan mekân üzerinden sosyal ayrışmaya neden olmaktadır.

\section{TOPLUMSAL ve MEKÂNSAL AYRIŞMANIN YENI BİÇIMİ: KAPILI TOPLULUKLAR}

Kamusal hayatı oluşturan kurallar kent mekânı içerisinde birbirlerini şekillendirirler. $\mathrm{Bu}$ bağlamda; "toplumsal gruplar homojen adacıklarda yaşamalı, kendilerinden farklı gördükleri ve etkileşimlerinin giderek koptuğu gruplardan uzak durmalıdır. Dolayısıyla yeni mekânsal ayrımlaşma yapısı yeni bir kamusal alan türünün temelini oluşturur" (Calderia; 1999, 87). Ancak bu kamusal alan özerk bir yapıya sahip olmaktadır. Oluşan homojen topluluklar kendilerini korumak için kararlarını kendileri alıp uygulamak istemektedirler. Bu bağlamda, bireyler konutlarında güven içerisinde olmaya çalışmaktadırlar. Konut, insanı koruyan, güven sağlayan mekânlardır. Temelde kendini koruma ve savunma güdüleri korku ile eşleştirilmektedir. Bireylerin kent içerisindeki temel kaygıları güvenlikli bir yaşamdır. Kentin mekânsal örgüsü, ekonomik ve toplumsal tabakalaşma ile ilgilidir. Bu süreç, kentleşme olgusunu farklı bir boyuta taşıyarak mekânın sosyal ve ekonomik olarak ayrımlaştığını göstermektedir. Metropoliten alanlardaki mekânsal örgütlenmeler kent merkezinin dışında bir yerleşim göstermektedir. Setha Low (2003), Behınd The Gates adlı eserinde başlangıç ifadeleri olarak yaşam, güvenlik, Amerikan Kentinde mutluğun peşinde gibi kelimeler kullanmıştır. $\mathrm{Bu}$ ifadeler gelişi güzel savrulan sözcükler değildir. Modern dünyada huzursuz birey, mutlu olmak için bireysel zevklere yönelerek tercihlerini mekâna yansıtmaktadır. Bunun en önemli nedeni, ekonomik düzeyin yükselmesi sayesinde bireyin geçim derdinin yerini bu tarz sinıfsal ayrımlarının almasıdır. Modern dünya karmaşık, huzursuz, güvensiz tiplerin kent sokaklarında cirit attığı, karmaşık, karanlık bir portre çizmektedir. Kapıların ardına saklanılmasının en önemli nedeni ötekilerden korkulmasıdır. Bu toplulukları tercih edenler, iş adamları, doktorlar, 
sanatçılar, akademisyenlerdir. Kapılı toplulukların içerisinde birey kendini kaygıdan uzak hissetmektedir. Çünkü yeni orta sınıf yoksulluktan korkmakta ve yoksulluğu görmezden gelmektedir (Low, 2003: 7-8). Burada amaç, çöken kent merkezinde mağdur olmamaktır. Bu yaklaşımlar, kültür bakımından ayrılan dünyada yeni bir yaşam tarzını beraberinde getirmiştir. Kapılı topluluklara taşınmanın ilk nedeni güvenlik olmakla birlikte devamında yaşam düzeyini yükseltmek, homojen gruplarla birlikte olma isteği gibi nedenler de siralanabilmektedir. İnsanlar bu kapılar ardında mutlu olmaktadırlar.

Konut hakkındaki değişimlerin yansıması en yaygın olarak "gated communities"dir. Dışa kapalı konut yerleşmeleri olarak tanımlanır. " "Edge cities"; kenar kentler (Garreau,1991), "fortified enclaves"; duvarlarla çevrelenmiş yerleşim bölgeleri (Calderia, 1996), "enclosed neighbourhood"; kapall mahalleler (Landman, 2000), "enclosed housing developments"; kapalı konut yerleşmeleri (Glasze, 2003), "gated enclaves"; kapılar ardındaki yerleşim bölgeleri (Grant, 2003) bu adlandırmalardan bazılarıdır” ( Tümer, 2008). Kapılı topluluk yerleşmeleri, refah adacıkları, kapalı cemaatler, korunaklı yerleşmeler gibi çeşitli tanımlarla Türkçe'ye çevrilen bu mekânlar eşitsizliğin mekânsal bir ifadesi olarak ön plana çıkmıştır. İçeride sakin ve homojen bir yaşam varken dişarısı karmaşık ve çöküntü içinde olabilmektedir. Birçok tanımı yapılan kent içerisindeki konut yerleşimleri, temelde kentin karmaşa ve kalabalığından daha sakin yerlere yönelen statü gruplarını içine almaktadır. Kullanılan kapılı topluluklar adlandırmasına en yakın yaklaşım Grant'ın "kapılar ardındaki yerleşim bölgeleri" adı olmuştur. Kapılı topluluklar; duvarlar, parmaklıklar, tel örgüler, kamuya açık olmayan, güvenlik sistemleriyle korunan, girişlerinin denetimli olduğu, kendi özel yönetimleri tarafından idare edilen yerleşmelerdir.

Dünyanın pek çok bölgesinde görülen kapılı topluluklar Amerika'da ortaya çıkmış, Güney Afrika, Hindistan, gibi ülkelerde devam etmiştir. Küreselleşen dünyada kapılı topluluklar eşitsizliği ve güç kavramını ön plana çıkarmıştır. "Mekân, her şekilde temel bir öneme sahiptir. Otorite, korku kültürü oluşturmaktadır” (Akgün; 2009). Bu korku kültürü, insanların devlete güvenmeyip, kendi adalet anlayışını getiren burjuva toplumunun oluşturduğu bir güçtür. Gelişen kapılı topluluklar arasında yol sistemi ve araç sahipliliği banliyöleşmeyi hızlandırmıştır. Bu oluşumun ardından kent ve banliyö arasındaki fiziksel uzaklık azalırken sosyal ve ekonomik uzaklıklar artmıştır. Kapılı topluluklar sınıf ayrımı üzerine kurulmuş bir mekânsal yapıdır. Kentten kopuş ve mekânsal yansıma 1950'lerde banliyöleşmenin parçası olan kapılı toplulukları ön plana çıkmaktadır. Kent içerisindeki sınırlar keskinleşmiş, kutuplaşma artmıştır. Sınıf ayrımının en net örneği, üst sınıfların kapılı topluluklara gerçek ya da sembolik duvarlar inşa edilmiş olmasıdır. Tarihsel çerçevede bakıldığında bu kapalı konutlara eski dönemlerde de rastlanılmıştır. Ancak küreselleşme süreciyle bu tarz konutlar çok daha ön plana çıkmıştır. Böylece kapılı topluluk kavramı evrensel bir olgu olmuştur. Kapılı topluluklar, dünyada 21. yüzyılın en hızlı gelişen konut yerleşmesi haline gelmiştir. Kapılı toplulukların kentleşmede yeni bir eğilim olarak ele alınmasına rağmen tarihsel süreç incelendiğinde, barınma, korunma ve güvenlik kaygılarıyla birlikte insanlığın tarih öncesi dönemden itibaren kendini çeşitli elemanlarla sınırlandırarak bir yaşam oluşturma eğiliminde olduğu ve gelir gruplarına bağlı olarak konut alanlarının farklılaştığı görülmektedir. Gelişmiş ülkelerde Sanayi Devrimi öncesinde kent merkezinde bulunan üst gelir grubunun konut alanlarının, sonrasında kent çeperlerinde oluşan banliyölere doğru kaydığg izlenmektedir.

Kapılı toplulukların, M.Ö 300'lere kadar gittiği iddiası vardır. İngiltere'de, Romalı askerlere ordudaki hizmetlerine karşıllk kentlerin duvarlarla çevrili kısmında arazi ve mülk verilmesiyle ön plana çıkmıştır. Antik kentlerin çoğunda sur vardır. Bu surların temel sebebi kenti düşman saldırılarından korumaktır. Tarihsel süreçte, ilk oluşum noktası güvenlik içinde yaşam isteği olan kapılı topluluklar, farklı coğrafyalarda sosyal ve mekânsal ayrımlaşma, kentin karmaşası, ekonomik refah ve statüleşme ile varlığını güçlendirmiştir. Ancak kapılı 
toplulukların varlığındaki en temel sebep güven içerisinde yaşama istediğidir. Kapılı topluluklar bu güven hissiyle oluşturulan kalelerle ortaya çıkmaya başlamıştır. Güvenlik önlemleri içerisinde duvarlar ve çitler bulunmaktadır. İçeride ise gözetleme kameraları ve silahlı korumalar olabilmektedir. Bu kapılı topluluklarda yaşayanlar güvenliği satın almışlardır. Kapılı topluluklar, kent kenarındaki ayrıcalık olarak da ifade edilmektedir. Güvenlik güdüsünü tamamlamak için kalabalık içinde ayrımlaşmış olarak bir yerleşim kurulmuştur. 21. yüzyılın sosyo-ekonomik özellikleri bu mekânları dış dünyaya kapatarak yönetimini birkaç otoriteyle sınırlandırmıştır. Kentin bütününden farklılaştırılmış bir topluluk oluşturulmuştur. Küresel kentler, gettoları üst sınıflar için ideal kent alanı olarak inşa etmiştir. Bu bağlamda, insanın ilk yerleşik hayata geçtiği zamandan günümüze barınma işlevindeki amaç sadece biçim değiştirmiştir. Mükemmel olmaya çalışan yerleşimler üst sınıflar için bir ayrıcalık gibi sunulmuştur. Ayrıcalık isteği eşitsizliği ve sosyal tabakalaşmayı beraberinde getirmektedir. Böylece sosyal statü ortaya konulmak istenmektedir. Gürültüden, trafikten, karmaşadan ve korkudan uzak yaşama isteği Batı dışında da talep görmekte, Amerikan tarzı bir hayat oluşturulmaya çalışılmaktadır. Ancak doğuda oluşum etnik farklılıklar üzerinde olmuştur. Oluşum nedenleri farklı olsa da sonunda sosyal statüye dayanılarak yerleşimler kurulmuştur. Toplumsal eşitsizliğin beraberinde getirdiği suç eğilimlerinden ve kentin karmaşasından uzaklaşma isteği sosyal statüye dayanarak yeni yapılanmalara yol açmıştır. Daha sonra kapılı topluluklar Kanada ve Meksika'da yaygınlaşmıştır. Kapılı topluluk oluşumlarının nedenleri arasında yatırım yapmak, benzer sosyal bir grup içerisinde yaşamak ve güvenli bir yaşam isteği vardır. "Amerika'da kapalı yerleşmelerin çoğu Dallas, Houston, Los Angeles, New Orleans, Long Island, New York, Chicago, Atlanta ve Washinghton'ın banliyölerinde görülmektedir, üstgelir grubu yanında orta ve alt gelir grupları da tüm kentlerde ve banliyölerde dışa kapalı konut alanlarında yaşamayı tercih etmektedir. Kapalı sitelerde yaşayanlar en çok beyazlar ve ülkenin batısı ile güney batısında nüfus oranı fazla olan Ispanyollardır. Los Angeles, Houston ve Dallas metropollerinde bir milyonu aşan ve duvarla çevrilmiş konut yerleşim alanı olduğu iddia edilmektedir" (Low, 2003) .

Yüksek eğitim ve gelir sahibi yeni orta sınıf arasında hem kendi konutlarından hem de aile konutundan şehir dışına doğru bir eğilim vardır. Sosyal çevre ve çocukların yetiştirileceği iyi bir ortam sağlamak ve konfor arayışının bir sonucu olarak gelişen bir sonuçtur. "Kamusal alanın özelleştirildiği bir yerleşim formu olarak bilinen kapılı yerleşim topluluklarına ilişkin çeşitli söylemler bulunmaktadır. Bunlar arasında en dikkat çekici olan; özellikle Sassen’in mega ve global kent söylemidir. Bir diğeri de, Blakey ve Snyder'in söylemidir” (Akgün; 2009). İlk söylem, günümüz kentini bir evrim sürecinin sonucu olarak görmektedir. Bu bağlamda; olması beklenen yaşanmaktadır. İkinci söylem ise, kültürü temsil etmektedir. Kapılar elit gruba güvenlik sağlamaktadır. Sosyal problemlerden izole hali söz konusudur. Kapılı topluluklar günümüzde olumlu yaklaşımlarla da ilgi çekmektedir. "Birçok kişi kapalı topluluk içinde bir aile yetiştirmenin faydal olduğuna inanmaktadır" (Edward; 2008). Bu tarz yerleşimlerde yaşayan bireyler özellikle çocukları için güvenli olduğunu vurgulamaktadır. Kapılı olmayan bir toplulukta yaşamak korku getirmektedir.

"Birçok kişi kapılı toplulukları olumsuz yönde de ön plana çıkarmaktadır. Heterojen bir topluma sırtımızı dönmekteyiz. Diğer insanlardan kendini soyutlamak yalnızlı̆̆a davet çıkarmaktır. Bu duvarlar bizi kalabalık içerisinde yalnız bırakacak ve iletişimi kısıtlayacaktır" (Edward;2008). Bu bağlamda, sınıf farkı ve statüleşme daha da ön plana çıkmaktadır. Kamuya ait sokaklar, korunaklı bir hale getirilerek tel örgülerle çevrelenmektedir. Aslında bu yöntem güvenliği daha da azaltmaktadır. Çünkü gizli ve farklı olan çoğunlukla dikkat çeker ve güvenliği azaltır. Bu toplulukların, güvenliği sağlayıp sağlamadığı sorgulanmaktadır. "Site sakinlerinin korkulu bakışlarla ve hızl adımlarla geçtikleri yeşil ve boş alanlar, terk edilmiş spor alanları ve loş otoparklar, kısa zamanda toplu konut sitelerinin alametifarikası oldu. 
Somut insanların inisiyatiflerine alan birakmayan, standart her ihtiyacın önceden düşünüldüğ̈̈ bu toplu konut siteleri, kentlerde sosyal yaşamın eti kemiği olan, özel yaşam alanların neredeyse bütünüyle yok ediyordu" (İnsel; 1999, 24). Yeni oluşan sınıf dışarıdan korktuğu için oturdukları sitelerdeki villalarına sağlam kilitler vurmaktadır. Bu korku, komşusunu tanımamayı, her gün karşılaştığı insanları yabancı gibi görmeyi ve dış dünyanın içeriye girmesini engellediği bir şizofren ruh hali oluşturmaktadır. Metropoliten alanların kendilerine özgü mekânsal yapılanması, işlevlerinden bağımsız olarak gelişmektedir. Dışa kapalılık özelliği ile mekânsal ilişkiler gelişince ötekileşmiş grup kendini soyutlamaktadır. Burada amaç kendi içinde kendine yetmektir. Bu yetebilmek, güvenlik, eğitim, kural koyma anlamında da kullanılabilmektedir. Mekânsal denetim düzeyi de kapılı topluluk için önemlidir. Dışa kapalılık mekân ve zaman denetimini kolaylaştırmaktadır.

Günümüzde Batı ve Güney Amerika'da planlama ve gelişim açısından çok dikkat çekmekle birlikte, sadece bu kıtada değil, Arjantin, Güney Afrika, Hindistan, İspanya, İngiltere, Fransa, Hollanda, Portekiz, Lübnan, Mısır, Çin gibi her kıtadan birçok ülkede görülmektedir. $\mathrm{Bu}$ tarz toplulukların bulundukları ülkeler için refah düzeyi ön plana çıkmaktadır. Devlet bu ülkelerdeki yaşam alanlarına olumlu bakmaktadır. Bu bağlamda, kapılı topluluklara bazı yetkileri vermiştir. Kapılı topluluklar hem avantaj hem de dezavantaja sahiptir. Yüksek yaşam kalitesi, güvelik sağlama, kontrollü trafik akışı ve çocuklar için uygun yaşam alanları, mahremiyeti daha kolay sağlama, aidiyet, özel bir yönetimin bulunması, sosyal aktiviteler gibi avantajlara sahiptir. Kentten kaçan birey bu avantajlar sayesinde huzurlu ve güvenli bir yaşam sürecektir. Ancak, şehir yaşamında bulunan heterojenliğin bozulmasıyla yalnızlaşma, kutuplaşma, kamusal alanın yok olması, çocukların yalnız büyümesi, acil durumlarda itfaiye gibi araçların siteye girişinde sorun çıkması sonucunda kapılı toplulukların olumsuz özellikleri pek çok yönden bireyi ve kenti etkilemektedir.

Kapılı topluluklar oluşum şekilleri, bulundukları yerler, sahip olduğu olanaklar açısından farklılık göstermektedir. $\mathrm{Bu}$ bağlamda; kapılı topluluklar, mekânların diğer mekânlarla olan ilişkisi bakımından derecelerine, kamusal özel ayrımlarına, hitap ettiği gruba göre ifadeler geliştirmişlerdir. Bu gelişmiş seçenekleri Blakey ve Synder (1997), Burke (2001), Grant (2003) oluşturmuşlardır. Her araştırmacı bir sınıflandırma oluşturmuştur. "Blakey ve Synder, sinıflandırmasında yerleşmelerin fiziksel özelliklerinden çok sakinlerin sosyal yapısına ve hangi amaçla o yerleşmeyi seçtiklerine dikkat etmektedir. Burke'in sınıflandırmasında ise, fiziksel yapılar ve bölgeler önem kazanmaktadır. Grant, fiziksel yapıları daha da özelleştirerek dışarıya kapanma şekillerini göz önünde tutarak sınıflandırma yapmıştır” (Tümer, 56: 2008). Kentin içinde ayrımlaşmayı duvar sağlamaktadır. Fiziksel duvar sosyal ayrımlaştırma oluşturmaktadır. Bu duvarla olan ayrım dışlamayı da beraberinde getirmektedir. Duvarın diğer tarafı merak uyandırdığı için toplumsal bir kutuplaşma meydana gelmekte ve bu kutuplaşma çatışmayı doğurabilmektedir. Kentsel şiddet ve suç korkusu, fiziksel konum, ekonomik ve politik faktörler bireyi daha da çok bu kapılı topluluklara itmiştir. Böylece fiziksel uzaklık farkından çok ön plana sosyal uzaklık çıkmaktadır.

Kapılı toplulukların oluşturduğu sosyal ayrımlaşma Türkiye'de ise 1970'li yılların sonunda kentleşme politikalarıyla başlamıştır. 1980'lerin sonunda da villa siteler ortaya çıkmıştır. İstanbul'un üst ve orta sınıfları küresel tüketim kültürünün etkisiyle, yaşadıkları kenti bir turist gibi bakarak yeniden keşfetmişlerdir. Tarihte olmadıkları kadar arınık mekânlar kurulmuş, kilise ve camiiler etrafındaki yapılardan arındırılmış ve kent çiçeklerle ve geniş parklarla doldurulmuştur. Bu düzenleme, aslında çöküntü alanlarının üzerinin kapatılmasıdır. Yoksul yerleşim alanları görmezden gelinerek bir süsleme yapılmıştır. Bu alanlarda kalan üst ve orta sınıf yeni bir ev ve yaşam alanı bulmak için kentin merkezini terk etmişlerdir. Kentin dışında toplu konut sitelerinde yaşayanlar, hayatlarından oldukça memnundurlar. "Türkiye, toplu konut siteleri konusunda, ilk kuşağın cicim aylarını mı yaşlyor sorusu hemen akla geliyor. 
Apartmanın standart olmaktan gelen cazibesi, buna denek düşen düzen tutkusu ve kişiliksiz, arınık mekân ve yaşan saplantısı ve yaşanılan çevrede homojenlik arayışı, toplu konut sitelerini Türk orta sınıfi için hala cazip kllyyor" (İncel, 1999: 24).

“Kapalı siteler, korunaklı site, güvenlikli site isimleriyle Türkiye'de ortaya çıkan kapılı topluluklar, güvenlikli sitelerin orta ve üst sinıfların küresel tüketim kültürüne eklemlenme isteğiyle şehir merkezinden kaçışı açıklamaktadır" (Öncü, 1997: 94). Bir bakıma Türk ekonomisinin dışa aç1lımı başlamıştır. Yeni bir zengin tipi olarak üst düzey yöneticiler ön plana çıkmıştır. Orta sınıf rüyası, farklılaşmış yerleşimleri ortaya çıkarmıştır. "90’lı yılların başından itibaren Ístanbul başta olmak üzere büyük kentlerin etrafinda boy veren lüks konut sitelerinin birinden içeri adımınızı atmışsanız anımsayacaksınızdır, sitenin bekçilerle korunan kapısından geçer geçmez alışılmadık bir manzara karşılar ziyaretçiyi: Türlü mimari detayla bezenmiş, pastel renklere boyalı bir örnek villalar; benzerlerine ancak beş yıldızlı otel bahçelerinde rastlanabilecek peyzaj düzenlemeleri; sezon dışı yazlık siteleri hatırlatan insansız sokaklar; dahası arkanızda bıraktı̆̆ını şehrin görsel ev mekânsal çeşitliliğiyle taban tabana zıt tekinsiz bir düzen" (Gönlügür, 2008: 73). Bu ifadeye göre, kapılı topluluklar ideal ev düzenini tamamen insan hayatını içe kapayarak, bu hayattan memnun kılınacak şekilde tüketiciye sunulmuş bir meta halinde hayatımızda yer almaktadır.

Kapılı topluluklar, Türkiye'de 1980'lerdeki ekonomik ve toplumsal dönüşümün sonucudur. Bu toplumsal dönüşüm, sosyal ayrışma kavramı ele alındığında eğitim düzeyi ve ekonomik duruma bağlı olarak ortaya çıkan farklılıklar ön plana alınmalıdır. Bu refah kararları piyasa ekonomisine göre alınmıştır. 1980 sonrası ekonomik yapılanma ile gelir dağılımı farklılaşmıştır. Böylece sosyal ayrışma üst sınıf kimliğini oluşturmuştur. Türkiye'de üst sınıf kimliği Batılı eksende ilerlemiştir. Böylece, İstanbul uluslararası finans merkezi haline gelmiş, gökdelenlerle ayrımlaşma eğilimi başlamıştır. Bu bağlamda, İstanbul'daki kentsel değişimin Batılılaşma eğiliminin ekonomik refahın bir göstergesi olduğu söylenebilmektedir. Üst düzey gelir grubuna dâhil kişilerin kentten kaçması sonucu, kent çeperinde bir yerleşim oluşmuştur. İstanbul'da, üst gelir grupları yaşam tarzı ve güvenlik satın almaya başlamışlardır. İstanbul' daki oluşum kent merkezine yakın ve kent merkezi dışında şekil almaktadır. Kapılı topluluklar, ayrıcalıklı ve ayrışmış (Fridin; 2006, 81) bir hayatı simgelerken alt gelir gruplarını ötekileştirmişlerdir. Ayrıcalık, spor alanları, yeşil alan, güvenlik sistemleri gibi noktalarda ön plana çıkarılmıştır. Bu ayrıcalıklar ne kadar fazlaysa o kadar pahalıdır.

Zenginlik, tüketimin niteliğiyle belirlenmeye başladığı anda mekâna yansımaktadır. Türkiye'de özellikle İstanbul'da kapılı topluluk örnekleri görülmeye başlanmıştır. İstanbul'da da tüm dünyadaki gibi zenginlik yüksek duvarlar arkasındaki farklılıklarla belirlenmektedir. Bu oluşan yeni sınıf, yerel yönetimlerin iktidar dönemini beslemiştir. Yasaları bu inşaatlara uygun hale getirmek için yeni imar politikaları çıkarılmıştır. Belde belediyeleri site inşaatlarında karşılaşılan yasal engelleri kaldırmaktadır. Gerekli inşaat ve düzenleme izinleri kolayca elde edilmektedir. Hatta kapılı toplulukların inşaatı konusunda arazi tercihleri ön plana çıkmıştır. Beykoz, Büyükçekmece gibi orman alanlarına konut inşa etmek isteyen firmalara kolaylık sağlanmıştır. Kamu ve belediye arazilerine usulsüz el koyma, üzerine kaçak yapı yapma sonucunda oluşan bu siteler bir süre sonra yasallaştırılmıştır. Kemer Country, Kemer Koleji ile başlayıp golf sahası ile devam edip, konut yerleşimine dönen ve milli parkın (Belgrad Ormanları) 170 hektarlık bir alanını kapsamaktadır. Bu durumu yasallaştırmak için, kamu arazisi 49 yıllığına kiralanmış, yasalar çıkmıştır. Kemer Country örneğinde "Toplam daire sayısı ve toplam blok sayısı, yerleşim içindeki yoğunluk konusunda genel bilgi vermektedir. Buna göre, Etiler semtinde bulunan Sarı Konaklar ve Maya Residence yoğun yerleşimler olarak görülmektedir. Daire tipleri genel olarak düz, villa, üç katll, çatı dubleksi, bahçe dubleksi gibi çeşitli tiplerde görülmektedir. Her bir örneğin kendi içinde özel güvenlik sistemleri mevcuttur ancak hırsızlık oranlarına bakıldı̆̆ında sürekli girişimler olan veya hırsızlığın yaşandı̆̆ı 
örnekler de görülebilmektedir” (Candaş, 2007: 43). Bu bağlamda, belirleyicilik diğer ülkelerde olduğu gibi güvenlik olgusu üzerindedir.

Kamunun gözünden uzakta, kararların duvarlar içinde alındığı, mahremiyetin gerektiği zaman gösterişle ön plana çıktığı, ötekilerden korkulan bir psikoloji oluşturulmuş yeni bir sınıf, yeni bir mekân oluşturmuştur: Kapılı topluluklar, güvenlikli siteler, refah adacıkları, 1980 sonrası politikacılar tarafından da desteklenen duvarlar arkasındaki yerleşimler İstanbul'dan sonra zamanla Türkiye'ye yayılmıştır. “Calderia 'nın Sao-Paulo üzerine yaptığ ç̧alışmada dışa kapalı/korunaklı adacıklar, Davis'in Los Angeles üzerine yaptığ çalışmada kapalı adacıklar diye adlandırllan türden refah adacıkları İstanbul'da 1980'lerin sonlarından itibaren ortaya çıkmaya başlamıştır” (Kurtuluş, 2007: 96). Bu yerleşimler sınıfsal kimliğe göre yapılanmıştır. Doktor, avukat, yöneticiler bu sınıfsal kimliği temsil etmektedirler. Ancak kapılı topluluk yerleşimlerinde kimlik mekânın mimarisi bakımından somutlaşmaktadır.

Kapılı topluluklar, kent yaşamına bir alternatif olarak doğmuştur. Sosyalliğin duvarlar ardında ön plana çıkması beklenmiştir. Bu yaşamı pazarlamak için de reklamlar organize edilmiştir. Bu bağlamda, üst ve orta sınıfın belirlediği kültürel kodlar, ortaya çıkan toplumsal ayrıcalık kalıpları bulunmaktadır. "Reklamlarda ilk göze çarpan tanıtım, ideal ev sözüdür. Küresel tüketime mekânı dâhil etmek amaçtır. Doğayla iç içe yaşam vaadi, şehrin, elektrik, su kesintisini hissettirmeyecek jeneratör, özel araba sahipliğinin mümkün kıldığ s şehirden uzakta bir yaşam" (Gönlügür, 2008: 74). Reklam kampanyaları şehirden uzak mekânlarda bu hayatın mümkün olduğunu vurgulamaktadır. Ötekilerden tecrit edilmiş bir yaşam hedeflenmektedir. Aynı zamanda, sitelerin reklam broşürlerinde şehir merkezindeki gürültü, trafikten, mal ve can güvenliğinden dolayı merkez uzak durulması gereken bir alan olarak ön plana çıkartılmıştır. Merkeze karşı, kent çeperindeki mutluluk, huzur ve düzen adacıkları önerilmektedir (Kurtuluş, 2007: 100). Bu bağlamda, kentsel güvenlik isteğinin oluşturduğu kapılı topluluk yerleşimleri günümüze bir tüketim unsuru olarak ulaşmış ve kent merkezlerinden uzaklaşmaya neden olmuştur. Kent çeperlerinde oluşan yaşam adacıkları yan yana yaşayan ancak aralarında sosyal mesafe bulunan yeni kentliler oluşturmuştur. Mekânların mesafeler açtığ 1 sosyo-ekonomik ayrımlaşma toplumsal kent yaşamının üzerinde belirgin farklar yaratmıştır. Güvenlik isteği bu sosyal mesafe nedeniyle güvensizlik durumuna dönüşmüştür. Günümüzde insanlar dişa kapalı konutlarda da güvensizlik yaşamaktadırlar. $\mathrm{Bu}$ güvensizlik hissinin nedeni ötekileştirilen insanların aslında bu konutlarda belli hizmet sektörleri içerisinde çalışıyor olmaları, kentlerde birlikte yaşamaya devam edilmesidir. Ayrıca, günümüzde kentliler kentsel dönüşüm pazarlarının oluşturduğu kent merkezlerinde yaptığı yatırımlarla kent merkezlerine geri dönmeye başlamışlardır.

\section{SONSÖZ}

Mekân ve insanın birbirlerini şekillendirmesi sonucunda mekânın toplumsal bir olgu olduğu gerçeği kentlerin ilk varlığıyla ortaya çıkmıştır. Antik Yunan kültürünün Polisi, Orta Çăg Avrupa'sının Kale kentleri ve kalelerin yıkılmasıyla genişleyip iktidarı temsil eden kent merkezleri... Hızla yaşanan toplumsal değişimin toplumların psikolojik yapısını da etkilemesiyle hız, bireysellik, yalnızlık ön plana çıkmıştır. Postmodern zamanlarda kentlerde bireysel bir başkaldırış söz konusudur. Bu bağlamda, söz yerine kimlikler, dış görünüş ve statü kentlilerin kendilerinin tanımlamasına neden olmaktadır. Bu bireysellik isteği ve içe kapanış başkalarının sahip olduğu ekonomik farklılığa ötekilerinin sahip olamamasına neden olmuştur. Bu durum ise, kent içerisinde oluşan mekânsal farklılığı kapılı topluluklarla ile göstermektedir. Kentlerin kalabalığından kaçan üst orta sınıfın ilgisini çeken kapılı topluluklar Türkiye'de 1980'li yıllarda ortaya çıkmaktadır. Kentliler o yıllardan sonra tüketim alışkanlıklarıyla kendilerini sınıflandırmışlardır. Bu tüketim alışkanlıklarına hızlı bir şekilde mekân da dâhil olmuştur. Kentin çeperlerinde oluşan kapılı topluluklar üst gelir gruplarına hitap etmektedir. Üst orta sınıf, kentin merkezindeki konutlarda güvenliği, lüksü, temizliği ve arınık bir hayatı 
satın almaktadır. Kapılı toplulukların tercih edilmesinin en büyük etkeni güvenlik ihtiyacının giderilmesidir. Kalabalıktan korkan birey güvensiz bir yaşam sürmek yerine denetimli bir yere taşınmaktadır. Ayrıca, statü farkı kapılı topluluklara verilen isimlerde de kendini göstermektedir. Yurt dışındaki Türkleri çekmek nedeniyle, küresel tüketime dâhil olmak için kapılı topluluklara, Country, city, home, rezidance gibi yabancı isimler verilmiştir. Bu etkenlerin yanında, postmodernizmin etkisiyle bazı kentlerde yabancı kelimeler kullanılırken bazılarında ise, geleneğe dönüş gerçekleşmektedir. Bazı kapılı topluluklar da eski İstanbul geleneğini Konak isimleriyle canlandırmaktadır.

Kapılı toplulukların, sınıf ayrımını ve ötekileştirmeyi sağlayan bir özelliği de yerleşimlerin etrafinda yükselen duvarlardır. Kapılı topluluklarda, güvenlik, sitelerin girişçıkışlarında, belli noktalarda kamera sistemleriyle de sağlanmaktadır. Kapılı topluluklar, bir duvar ve tel örgü ile kentten yalıtılmıştır. Ancak, bu kapalılık olumsuz mesaj verebilmektedir. Potansiyel suçlar artmakta, ayrıca içeride de hırsızlıklar yükselmektedir. Kapılı toplulukların kente uzak olmasının sonuçları duruma göre değişmektedir. Eğer kapılı topluluk büyük bir kentin çeperindeyse, işe gidip gelen sınıf için ulaşım yoğun olmaktadır. Ancak, daha az yoğun bir kentin çeperindeyse ulaşım sorun olmamaktadır.

Sonuç olarak, kapılı topluluklar, güvenlik, tasarım, temizlik, kalite, peyzaj sanatı, gösteriş yerleşimleri açısından olumlu bulunmaktadır. Ancak mekân aracılığıyla sınıf ayrımını derinleştirerek sosyo-ekonomik açıdan ötekileştirme yaşatmaktadır. Türkiye açısından özel tüketim alışkanlıkları, özendirilerek devlet eliyle de ön plana çıkarılmıştır. Bu konutların, oluşumundaki temel bakış açısı kaliteli, ferah, güvenlikli bir hayat sunmaktadır. Türkiye'de, son yirmi yılda kent merkezinde bunalan üst orta sınıf kent çeperlerine kaçarak, kaliteyi, hayat tarzını, güvenliği satın almaktadır. Fakat kendini izole eden birey gün geçtikçe yalnızlaşmıştır. Yalnızlaştıkça evlerine daha da kilit vurmuşlardır. Kapılı topluluklar, fiziksel duvarlar örerken, sosyal dünyaya da duvarlar örmüştür. 


\section{KAYNAKÇA}

AKGÜN, A, (2009), La Zona (Yasak Bölge) : İktidarın Gücü Olarak Mekân, Mekân Araştırmaları, İstanbul Kültür Üniversitesi.

ALVER, K, (2010), Steril Hayatlar, Ankara: Hece Yayınları.

ARAPKİRLİĞLU, K, YENER, Z, (2012), “Avrupa Kentsel Şartı”, İçişleri Bakanlığı Mahalli İdareler Genel Müdürlüğü, Ankara.

ASLANOĞLU, R, (2000), Kent Kimlik ve Küreselleşme, Bursa: Ezgi Kitabevi.

AYTAÇ, Ö, (2007), “Kent Mekânlarının Sosyo-Kültürel Coğrafyası”, Fırat Üniversitesi Sosyal Bilimler Dergisi, Say1 2.

BALİ, R. N. (1999), Çılgın Kalabalıktan Uzakta, İstanbul: Birikim Yayınları.

BALİ, R. N, (2000), Tarz-I Hayattan Life Style'a, Yeni Seçkinler, Yeni, Mekânlar, Yeni Yaşamlar, İstanbul: İletişim Yayınları.

BAUDRILLARD, J, (2004), Tüketim Toplumu, İstanbul: Ayrıntı Yayınları

CALDERIA, (1999), “Duvarlar İnşa Etmek”, Birikim Dergisi, Sayı: 123.

CANDAŞ, E, (2007), “İstanbul'da Dışa Kapalı Konut Sitelerinin Tasarımında Güvenlik Konusunun İrdelenmesi, Yüksek Lisans Tezi, İstanbul Teknik Üniversitesi, Fen Bilimleri Enstitüsü, Mimarlık Bölümü

DANIŞ, D, (2005), “Zenginliğin Mekânda Yeni Yansımaları: İstanbul'da Güvenlikli Siteler”, Toplum Bilim Dergisi, Say1: 104.

ERDER, S, (2006), Refah Toplumunda Getto, İstanbul: İstanbul Bilgi Üniversitesi Yayınları.

FRIDIN, E, (2006), "Sosyal Ve Mekânsal Ayrışma Çerçevesinde Yeni Konutlanma Eğilimleri: Kapalı Siteler, İstanbul, Çekmeköy Örneği”, Planlama Dergisi, Sayı: 4.

FRIDIN, E, (2006), "Sosyal Ve Mekânsal Ayrışma Çerçevesinde Yeni Konutlaşma Eğilimleri: Kapalı Siteler, İstanbul-Çekmeköy Örneği, Doktora Tezi, Msgsü Fbe.

GÖNLÜGÜR, E, (2008), “Kentsel Ayrışmanın Yeni Alemet-İ Farikası Kapalı Cemaatler”, Birikim Dergisi, Sayı: 232-233.

KAYPAK, Ş, (2013), “Kentsel Güvenlik Açısından Mahallenin Önemi”, Kaysem 8 Bildiri Kitabl, Ankara: Pegem Yayınları.

KURTULUŞ, H, (2005), İstanbul'da Kapalı Yerleşmeler, Beykoz Konaklarl Örneği, İstanbul'da Kentsel Ayrışma, İstanbul: Bağlam Yayınları

KURTULUŞ, H, (2003), "Mekânda Billurlaşan Kentsel Kimlikler: İstanbul'da Yeni Sınıfsal Kimlikler Ve Mekânsal Ayrışmanın Bazı Boyutları”, Doğu-Batı: Kimlikler- Sayı 23

KURTUlUŞ, H, (2005), Bir Ütopya Olarak Bahçeşehir, İstanbul'da Kentsel Ayrışma: Mekânsal Dönüşümde Farklı Boyutlar İçinde, İstanbul: Bağlam Yayınları

KURTULUŞ, H. (2005), “Refahın Yeni Mekânsal Temsilleri”, Mostar Dergisi, Sayı: 55

LOW, S, (2004), Behind The Gates, Life, Security Ant Pursuit Of Hapiniess In Fortress America, Routledge, $\mathrm{Ny}$

ÖNCÜ, A. (1999), “İdealinizdeki Ev Mitolojisi Kültürel Sınırları Aşarak İstanbul’a Ulaştı”, Birikim Dergisi, Sayı: 123. 
ÖNCÜ, A. (2005), Mekân, Kültür, İktidar, Küreselleşen Kentlerde Yeni Kimlikler, İstanbul: İletişim Yayınları

TURNER, B, (2001), Statü, Ankara: Ütopya Yayınları.

TÜMER, Ö, (2008), “Bursa'da Kapalı Konut Yerleşmelerinin Oluşum Süreci ve Sınıflandırması”, Uludağ Üniversitesi Mühendislik Mimarlık Dergisi, Sayı: 2.

UYSAL, Y, (2003), "Parçalanan Kent-Parçalanan Yaşamlar, Kentin Çeperleri”, Mimarist Dergisi, Sayı: 8

YARDIMCI, S, (2009), “Özel Güvenlik, Kent Yaşamı Ve Yönetimsellik”, Toplum ve Bilim Dergisi, Say1: 115. 